\title{
How do leaf anatomies and photosynthesis of three Rhododendron species relate to their natural environments?
}

Yan-Fei Cai ${ }^{1,2,3}$, Shi-Feng Li $i^{1,2,3^{*}}$, Shu-Fa Li ${ }^{1,2,3}$, Wei-Jia Xie ${ }^{1,2,3}$ and Jie Song ${ }^{1,2,3}$

\begin{abstract}
Background: Rhododendron is one of the most well-known alpine flowers. In order to identify performances relating to Rhododendron's natural habitats we investigated the leaf anatomical structures and photosynthetic characteristics of $R$. yunnanense, R. irroratum and $R$. delavayi, which showed different responses after being transplanted into a common environment.
\end{abstract}

Results: When compared with $R$. irroratum and $R$. delavayi, $R$. yunnanense had lower leaf dry mass per unit area (LMA) and larger stomata, but smaller stomatal density (SD) and total stomata apparatus area percent (At), lower stomatal conductance (Gs), transpiration rate (Tr), light compensation point (LCP), light saturation point (LSP), light-saturated photosynthetic rate (Amax) and leaf nitrogen content per unit area (Na). LMA was positively correlated with Amax and maximum rates of carboxylation (Vcmax). However, leaf $\mathrm{N}$ content was not significantly correlated with Amax. Thus, the variation in leaf photosynthesis among species was regulated largely by changes in LMA, rather than the concent of nitrogen in leaf tissue.

Conclusions: $R$. yunnanense plants are vulnerable to moisture and light stress, while $R$. irroratum and $R$. delavayi are better suited to dry and high radiation environments. The present results contribute to our understanding physiological trait divergence in Rhododendron, as well benefit introduction and domestication efforts for the three species of Rhododendron studied in this work.

Keywords: Leaf anatomy; Photosynthesis; Rhododendron

\section{Background}

Rhododendron is one of the most well-known alpine flowers. The genus of Rhododendron contains 1000 species distributed in Asia, Europe, and North America. China has the most diverse Rhododendron flora with 571 species; 320 species of which occur solely within the Yunnan province of Southwestern China (Fang et al. 2005). However, the distribution of many species is usually narrow in Yunnan province. For example, $R$. oxyphyllum and $R$. yunnanense are mainly distributed in mixed forests on slopes, whereas $R$. wardii and $R$. irroratum are found in evergreen broad-leaved forest or mixed forest, and $R$. decorum, $R$. siderophyllum and $R$. delavayi

\footnotetext{
* Correspondence: lishifeng1970@foxmail.com

${ }^{1}$ Flower Research Institute of Yunnan Academy of Agricultural Sciences, Kunming 650205, China

${ }^{2}$ Yunnan Flower Breeding Key Lab, Kunming 650204, China

Full list of author information is available at the end of the article
}

are found in thickets, hills, rocky slopes or single-species constitute the forest (Fang et al. 2005).

Because of its popularity, the demand of Rhododendron genus as an ornamental plant has been increasing in recent years. Large-scale cultivation under controlled conditions is necessary to meet this rising demand. Successful cultivation and continued use of wild species require knowledge of their requirements for optimal growth (Cui et al. 2004). However, few studies have examined the growing conditions of Rhododendron, such as water availability, temperature, nutrient availability, and photoprotective cover for overwintering (Cordero and Nilsen 2002; Scagel 2007; Wang et al. 2009).

Photosynthesis is widely used as a tool for indicating environmental stress and selection of growth conditions suitable for different species (Weng and Ueng 1997). The knowledge of leaf structural and physiological characteristics of species and how these triats relate to their 
physical habitats is essential for introduction and domestication programs (Guan et al. 2011; Zhang and Yin 2012), and subsequent commercial production. Indeed, although several numbers of Rhododendron have been cultivated for centuries, it is still not an easy task because the optimum growing condition remains unclear.

Species' distribution patterns reflect trait-habitat interaction and determined by the plant ecological functions. Plant structure is the basis of function, so the differences and changes of structure will inevitably affect physiological and ecological function, and thus, the adaptability of plants to a changing environment (Kikuzawa 1995; Poorter and Bongers 2006). After transplanting from their natural habitat to the nursery in Kunming without any protection measures, Rhododendron species exposed to these different environment (hotter, drier and more radiation) showed divergent responses. For example, $R$. yunnanense grew poorly, with its leaves exhibiting significant light damage, such as leaf chlorosis and sun burn spots, while $R$. decorum and $R$. delavayi maintained normal growth, but with reduced flower size.

The growth and development of plants in such different environments depends on their physiological tolerance, which in turn, relates back to their original habitats. $R$. delavayi and $R$. irroratum are mainly distributed in evergreen broad-leaved forests margins, whereas $R$. yunnanense grow in mixed forests on shaded slopes. Consequently, the most obvious difference of their nature habitat is that $R$. delavayi and $R$. irroratum are subjected to stronger light intensity than is $R$. yunnanense (Fang et al. 2005). We hypothesized that the difference in light intensity influences the distribution of these species of Rhododendron.

Light is one of the most important driving forces of leaf photosynthesis, which in turn determines a plant's growth, survival and fitness. In response to changes in light environment, plants acclimate to different light availabilities mainly through changes in leaf anatomical features (particularly changes in leaf mass per unit area, LMA), or by changes in biochemical features (particularly leaf nitrogen content and leaf nitrogen partitioning among different photosynthetic machinery), or both (Feng 2008; Evans and Poorter 2001; Lin and Hsu 2004). However, ecological studies have generally focused on anatomical features without distinguishing changes in leaf nitrogen content, and physiological studies have concentrated on the importance of biochemical changes without considering the importance of changes in structure (Le Roux et al. 2001). The relative importance of these anatomical and physiological variations within a given plant material is not well understand (Le Roux et al. 1999).

The leaves of a plant are the main apparatus for photosynthesis and respiration, and closely link with the surrounding environment. In the evolution of plants, leaves are the most sensitive organs and the plasticity is the largest to the environment. Leaf structural features contributing to the maintenance of the high $\mathrm{CO}_{2}$ concentration in the chloroplast stroma may have been selected during evolution (Dunbar-Co et al. 2009). Therefore, the research for leaf traits indicative of leaf performance is crucial to understanding of the ecological function and the distribution of plant species (Vendramini et al. 2002; Pandey et al. 2009).

In this study, we investigate leaf anatomical structure and photosynthetic characteristics of three Rhododendron species that showed different responses when grown under the same environment. Our aim was to identify their divergent performances relating to natural habitat, and evaluate the relative importance of leaf anatomy and physiology in relation to their natural habitats. The relationships between leaf anatomy and physiological aspects are particularly emphasized.

\section{Methods}

\section{The study site and plant materials}

Three year old plants of $R$. yunnanense, $R$. irroratum and $R$. delavayi were collected from their natural habitats in the east of Yunnan province, China (alt. 1500$\left.2409 \mathrm{~m}, \mathrm{E} 103^{\circ} 42^{\prime}-104^{\circ} 34^{\prime}, \mathrm{N} 24^{\circ} 20^{\prime}-25^{\circ} 00^{\prime}\right)$. This site has a subtropical mountain climate, and the main vegetation is conifer and broad-leaved mixed forest. The ecological characteristics and biological traits considered are shown in Table 1 in Fang et al. (2005). Three Rhododendron species were cultivated in a nursery in Kunming,

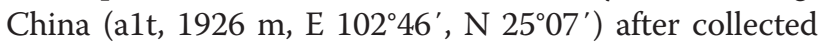
them from the field. The mean annual temperature and mean annual rainfall were $14.5^{\circ} \mathrm{C}$ and $1035.3 \mathrm{~mm}$, respectively. The seedlings were grown into $3-\mathrm{L}$ plastic pots (one plant per pot) filled with a laterite-humus $(\mathrm{V} / \mathrm{V}$, $1 / 3$ ), shaded by a nylon net to give $40-50 \%$ of full sunlight, and then watered and fertilized as needed to ensure nonlimiting water and nutrient supply. After cultivation for 18 months, the plants were used for measurements in the present study.

\section{Gas exchange measurements}

Gas exchange measurements were made on the fully expanded, mature leaves using a portable LI-6400XT photosynthesis system (LI-Cor, Lincoln, NE, USA) equipped with a red/ blue LED light source (6400-02B) in July 2010. The response curve of net photosynthetic rate $\left(A_{n}\right)$ to irradiance (PAR) was determined at light intensities

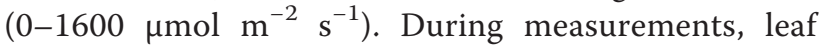
temperature $\left(\mathrm{T}_{\text {leaf }}\right)$ was controlled at $20^{\circ} \mathrm{C}, \mathrm{CO}_{2}$ concentration $\left(\mathrm{C}_{\mathrm{a}}\right)$ and relative humidity $(\mathrm{RH})$ in the cuvette were held at $370 \mu \mathrm{mol} \mathrm{mol}{ }^{-1}$ and $60-70 \%$, respectively. $\mathrm{A}_{\mathrm{n}}-\mathrm{C}_{\mathrm{i}}$ curve was determined with a range of $\mathrm{CO}_{2}$ concentrations $\left(0-2000 \mu \mathrm{mol} \mathrm{mol}^{-1}\right)$ under a controlled light intensity $\left(800 \mu \mathrm{mol} \mathrm{m}{ }^{-2} \mathrm{~s}^{-1}\right) . \mathrm{T}_{\text {leaf }}$ and $\mathrm{RH}$ were controlled as the same with $A_{n}$-PAR curves. Three mature leaves 
Table 1 Ecological characteristics and biological traits of three Rhododendron species

\begin{tabular}{llll}
\hline Species & R. yunnanense & R. irroratum & R. delavayi \\
\hline Life form & Shrubs, rarely small trees & Shrubs or small trees & Shrubs or trees \\
Distribution & Guizhou, S Shanxi, W Sichuan, Xizang, & W Guizhou, SW Sichuan, N and & NW Guangxi, W Guizhou, SW Sichuan, \\
& Yunnan & SE Yunnan & SE Xizang, Yunnan \\
Altitude (m) & $2200-3600$ & $1700-3500$ & $1200-3200$ \\
Habitat & Mixed forests on shade slopes, & Evergreen broad-leaved forests, & Mixed forests, evergreen broad-leaved \\
& Abies-Picea or Pinus-Quercus forest & mixed forests & forests, forest margins, thickets, hills, rocky \\
& margins, thickets & & slopes, open field \\
Flower period & Apr-Jun & Mar-May & May \\
Fruit period & Sep-Oct & Sep-Oct & Dec \\
\hline
\end{tabular}

from three individual plants per species were selected for photosynthetic measurement. $\mathrm{A}_{\mathrm{n}}$, stomatal conductance $\left(\mathrm{G}_{\mathrm{s}}\right)$ and transportation rate $\left(\mathrm{T}_{\mathrm{r}}\right)$ were recorded automatically during measurements. Water use efficiency (WUE) was calculated as dividing $A_{n}$ by $T_{r}$. Values of $G_{s}$ and WUE were measured at $C_{a}$ of $370 \mu \mathrm{mol} \mathrm{mol}^{-1}$ and PAR of $800 \mu \mathrm{mol} \mathrm{m} \mathrm{m}^{-2} \mathrm{~s}^{-1}$. Light-saturated photosynthetic rate $\left(\mathrm{A}_{\max }\right)$, dark respiration rate $\left(\mathrm{R}_{\mathrm{d}}\right)$, light saturation point (LSP) and light compensation point (LCP) were calculated from the $A_{n}$-PAR curve with a three-component exponential function (Watling et al. 2000): $A_{n}=a\left(1-e^{-b x}\right)+C$, where $A_{n}$ is photosynthetic rate, $x$ is PAR, $a, b$ and $C$ are constants. Maximum rates of carboxylation $\left(\mathrm{V}_{\mathrm{cmax}}\right)$ was estimated from the $A_{n}-C_{i}$ curve with Photosyn Assistant software (Dundee Scientific, Scotland, UK) that applied the biochemical model described by Von Caemmerer and Farquhar (1981).

\section{Leaf properties and anatomical measurements}

After the gas exchange measurements, 9 mature leaves from 3 individual plants for each species were harvested for subsequent analysis. Chlorophyll content was determined using a spectrophotometer UV-751GD (Shanghai Analytical Instrument Co., China) and was calculated according to the method of Inskeep and Bloom (1985). Leaf area was measured with a leaf area meter LI-3000A (LI-COR, Inc., Nebraska, USA). Leaf dry weight was obtained after oven-drying at 80 for $48 \mathrm{~h}$. Leaf dry mass per unit area (LMA) was calculated using these data. The dried leaf samples used for LMA measurement were collected and use for leaf nitrogen content per area $\left(\mathrm{N}_{\mathrm{a}}\right)$ analyses with an automatic elemental analyser (Vario EL, Elementar Analysensysteme GmbH, Hanau, Germany). The partitioning coefficients for leaf nitrogen in RuBPCO $\left(\mathrm{P}_{\mathrm{R}}\right)$ and bioenergetics $\left(\mathrm{P}_{\mathrm{B}}\right)$ were estimated according to the method of Niinemets and Tenhunen (1997). The values of $P_{R}$ and $P_{B}$ were calculated as follows:

$$
\begin{aligned}
& P_{B}={ }^{J \max } / 8.06 N_{m} J_{m c} L M A \\
& P_{R}={ }^{V c \max } / 6.25 N_{m} V_{c r} L M A
\end{aligned}
$$

The values of $\mathrm{V}_{\mathrm{cr}}$ and $\mathrm{J}_{\mathrm{mc}}$ at $20^{\circ} \mathrm{C}$ were equal to $12.6 \mu \mathrm{mol}$ (CO2) $\mathrm{g}^{-1}$ (RuBPCO) $\mathrm{s}^{-1}$ and $131.9 \mathrm{~mol}$ (electron) $\mathrm{mol}^{-1}$ cyt $\mathrm{f} \mathrm{s}^{-1}$, respectively. $\mathrm{N}_{\mathrm{m}}$ was mass-based leaf nitrogen content (\%). The PNUE was calculated as $\mathrm{A}_{\max } / \mathrm{N}_{\mathrm{a}}$.

Small pieces from the middle region of the leaves were fixed in FAA (formalin/ glacial acetic acid/ 50\% ethanol, V/ V/ V, 5/ 5/ 90) for at least $24 \mathrm{~h}$, then dehydrated by gradient ethanol, cleared in xylene, and then embedded in paraffin for sectioning. 8- $\mu \mathrm{m}$ thick sections were cut using a Microm HM 315 rotary microtome (Microm Laborgeraet GmbH, Germany) and then mounted on glass slides. The samples were examined and photographed using a Nikon Eclipse E800 light microscope (Nikon, Melville, NY, USA). Cuticle, epidermis, mesophyll, palisade tissue, spongy tissue and leaf thickness were measured with image ProPlus 6.0 software at $400 \times$ magnification (Media Cybernetics, Inc., Sliver Spring, MA, USA).

Small sections cut out from the middle section of leaves (ca. $0.5 \times 0.5 \mathrm{~cm}$ ) were placed in a $50 \%$ sodium hypochlorite solution until the leaves turned white, and then peeled adaxial and abaxial epidermis after washing with distilled water and photographed under a light microscope. Digital images were analyzed with ProPlus 6.0 software at $400 \times$ magnification. The stomatal density $\left(\mathrm{S}_{\mathrm{D}}\right)$, stomatal apparatus area $\left(\mathrm{A}_{\mathrm{s}}\right)$ and total stomatal apparatus area percent $\left(\mathrm{A}_{\mathrm{t}}\right)$ were calculated as follows: $\mathrm{S}_{\mathrm{D}}=\mathrm{N} / \mathrm{S}, \mathrm{A}_{\mathrm{S}}=1 / 4 \times \pi \times \mathrm{l} \times \mathrm{w}, \mathrm{A}_{\mathrm{t}}=\mathrm{A}_{\mathrm{S}} \times \mathrm{S}_{\mathrm{D}} \times 100 \% . \mathrm{N}$ denotes the number of stomata, $S$ is the area of observation, and 1 and $\mathrm{w}$ are the stomatal apparatus length and width. Three leaves from three individuals were examined for each species, and more than ten images per leaf were analyzed.

\section{Statistical analysis}

Statistical analysis was performed with SPSS 13.0 (SPSS Inc., Chicago, USA). Difference between means were tested by one-way ANOVA and LSD multiple comparisons tests. Difference was considered significant at $\mathrm{p}<0.05$. All graphs were carried out in the software SigmaPlot for windows version 9.0 (Systat Software, Inc.). 
Table 2 Leaf anatomical structure and stomatal characteristics of three $\mathbf{R h o d o d e n d r o n ~ s p e c i e s}$

\begin{tabular}{lccc}
\hline Parameters & R. yunnanense & R. irroratum & R. delavayi \\
\hline $\mathrm{LT}(\mu \mathrm{m})$ & $262.42 \pm 0.98 \mathrm{a}$ & $247.47 \pm 1.63 \mathrm{~b}$ & $243.98 \pm 2.57 \mathrm{~b}$ \\
$\mathrm{CT}(\mu \mathrm{m})$ & $2.76 \pm 0.12 \mathrm{c}$ & $5.93 \pm 0.11 \mathrm{a}$ & $3.76 \pm 0.10 \mathrm{~b}$ \\
$\mathrm{ET}_{\mathrm{ad}}(\mu \mathrm{m})$ & $40.09 \pm 0.46 \mathrm{a}$ & $39.45 \pm 0.32 \mathrm{a}$ & $35.46 \pm 0.46 \mathrm{~b}$ \\
$\mathrm{ET}_{\mathrm{ab}}(\mu \mathrm{m})$ & $13.93 \pm 0.33 \mathrm{a}$ & $7.98 \pm 0.11 \mathrm{~b}$ & $7.18 \pm 0.14 \mathrm{c}$ \\
$\mathrm{PT}(\mu \mathrm{m})$ & $91.53 \pm 0.80 \mathrm{a}$ & $84.31 \pm 0.59 \mathrm{~b}$ & $91.35 \pm 2.03 \mathrm{a}$ \\
$\mathrm{ST}(\mu \mathrm{m})$ & $114.94 \pm 1.03 \mathrm{a}$ & $109.86 \pm 1.50 \mathrm{~b}$ & $105.30 \pm 1.83 \mathrm{~b}$ \\
$\mathrm{PT} / \mathrm{ST}$ & $0.81 \pm 0.01 \mathrm{~b}$ & $0.78 \pm 0.01 \mathrm{~b}$ & $0.89 \pm 0.03 \mathrm{a}$ \\
$\mathrm{S}_{\mathrm{D}}\left(\mathrm{mm}{ }^{2}\right)$ & $198.56 \pm 4.20 \mathrm{c}$ & $501.00 \pm 11.17 \mathrm{~b}$ & $810.99 \pm 15.32 \mathrm{a}$ \\
I $(\mu \mathrm{m})$ & $17.99 \pm 0.32 \mathrm{a}$ & $11.74 \pm 0.15 \mathrm{~b}$ & $10.22 \pm 0.18 \mathrm{c}$ \\
W $(\mu \mathrm{m})$ & $11.06 \pm 0.20 \mathrm{a}$ & $7.77 \pm 0.12 \mathrm{~b}$ & $6.40 \pm 0.15 \mathrm{c}$ \\
$\mathrm{A}_{s}\left(\mu \mathrm{m}^{2}\right)$ & $620.44 \pm 13.98 \mathrm{a}$ & $345.26 \pm 5.02 \mathrm{~b}$ & $243.17 \pm 5.66 \mathrm{c}$ \\
$\mathrm{A}_{t}(\%)$ & $11.07 \pm 0.28 \mathrm{c}$ & $18.09 \pm 0.33 \mathrm{~b}$ & $21.03 \pm 0.50 \mathrm{a}$ \\
\hline
\end{tabular}

Mean \pm SE $(n=50) L T$, leaf thickness; CT, cuticle thickness; $E_{a d}$, adaxial epidermis cell thickness; $\mathrm{ET}_{\mathrm{ab}}$, abaxial epidermis cell thickness; $\mathrm{PT}$, palisade tissue thickness; ST, spongy tissue thickness; PT/ST, ratio of palisade and spongy tissue; $S_{D}$, stomatal density; $L$, stomatal length; $W$, stomatal width; $A_{S}$, stomatal apparatus area; $A_{t}$, total stomatal apparatus area percent. Different letters in the same row indicate statistical difference $(p<0.05)$.

\section{Results}

\section{Leaf anatomical structure}

Leaf thickness (LT) of three Rhododendron species varied from 243.98 to $262.42 \mu \mathrm{m}$, with $R$. yunnanense having the thickest leaves $(262.42 \mu \mathrm{m})$. Adaxial epidermis cell thickness $\left(\mathrm{ET}_{\mathrm{ad}}\right)$, abaxial epidermis cell thickness $\left(\mathrm{ET}_{\mathrm{ab}}\right)$ and mesophyll tissue thickness (palisade and spongy tissue thickness, PT and ST) contributed to higher leaf thickness of $R$. yunnanense (Table 2). However, cuticle thickness $(\mathrm{CT})$ and ratio of palisade and spongy tissue (PT/ST) were lower in $R$. yunnanense. $R$. delavayi had the lowest LT and highest PT/ST, whereas $R$. irroratum was in the middle (Table 2).

Adaxial epidermal cells of three Rhododendron species are rectangular or ellipse and closely arranged in two layers of cell (Figure 1). The shape of epidermal cells of $R$. yunnanense and $R$. irroratum were wavy (Figure 2a and $\mathrm{b}$ ), whereas $R$. delavayi had polygon-shaped epidermal cells (Figure 2c). Oval stomata were only found on the leaf abaxial surface among the three Rhododendron species (Figure 2). There were significant differences in stomatal characteristics among the considered species. The stomatal density $\left(\mathrm{S}_{\mathrm{D}}\right)$ and total stomatal apparatus area percent $\left(\mathrm{A}_{\mathrm{t}}\right)$ were lowest in $R$. yunnanense, and highest in $R$. delavayi. Stomatal length (l), stomatal width (w) showed opposite trends with $S_{D}$ and $A_{t}$ (Table 2).

\section{Leaf photosynthetic capacity}

$R$. delavayi and $R$. irroratum had higher $\mathrm{A}_{\max }$, LCP, LSP, $R_{d}$, and $V_{c \max }$, and were significantly different from $R$. yunnanense $(\mathrm{p}<0.05)$ (Table 3$)$. However, there were no significant differences between $R$. delavayi and $R$. irroratum. Furthermore, $R$. yunnanense had the lowest intercellular $\mathrm{CO}_{2}$ concentration $\left(\mathrm{C}_{\mathrm{i}}\right)$ at atmospheric $\mathrm{CO}_{2}$ concentration of $370 \mu \mathrm{mol} \mathrm{mol}{ }^{-1}$ among the three species (Table 3 ), possibly a result of lower $G_{s}$ $\left(0.144 \mathrm{~mol} \mathrm{~m}^{-2} \mathrm{~s}^{-1}\right)$. Lower $\mathrm{G}_{\mathrm{s}}$ also resulted in lower $\mathrm{T}_{\mathrm{r}}$ in $R$. yunnanense, and therefore improved water use efficiency (WUE). $R$. delavayi and $R$. irroratum showed opposite trend with $R$. yunnanense, and with higher values of $G_{\mathrm{s}}, C_{\mathrm{i}}$, $\mathrm{T}_{\mathrm{r}}$ and lower value of WUE.

\section{Leaf properties}

LMA of $R$. irroratum was significantly higher than $R$. yunnanense, but similar to that of $R$. delavayi (Table 4).

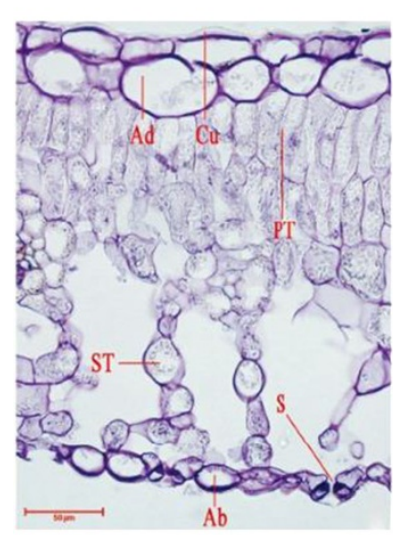

(a)

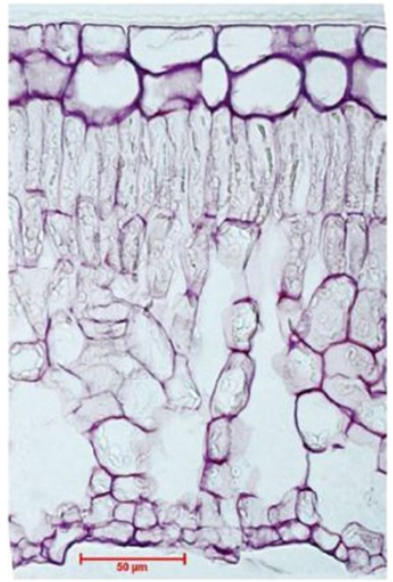

(b)

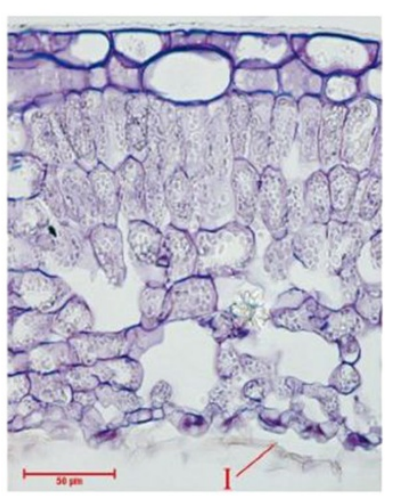

(c)

Figure 1 Leaf cross sections of Rhododendron yunnanense (a), R. irroratum (b), and R. delavayi (c) under light microscope. Cu, cuticle, $A_{d}$, adaxial epidermis, PT, palisade tissue, ST, spongy tissue, $A_{b}$, abaxial epidermis, S, stomata. I, indumentum. Scale bars $50 \mu m$. 


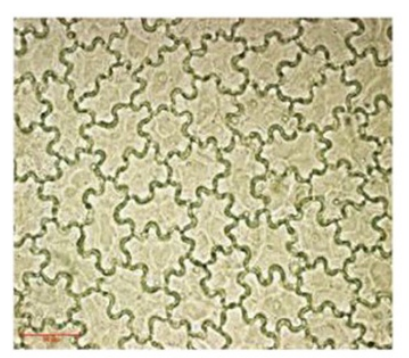

(a)

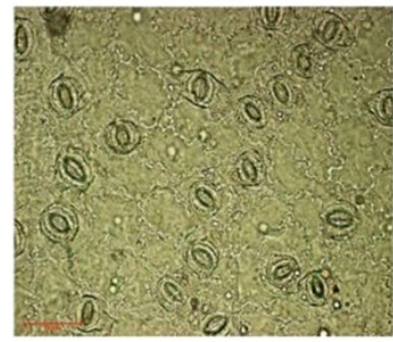

(d)

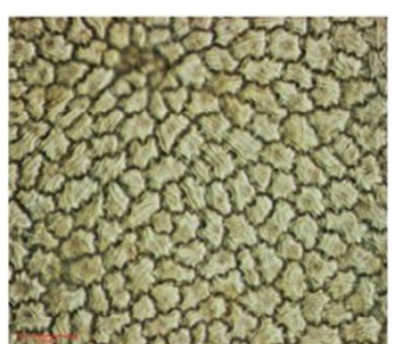

(b)

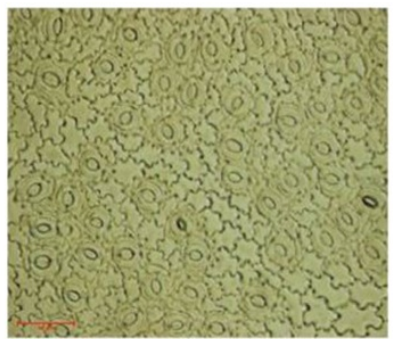

(e)

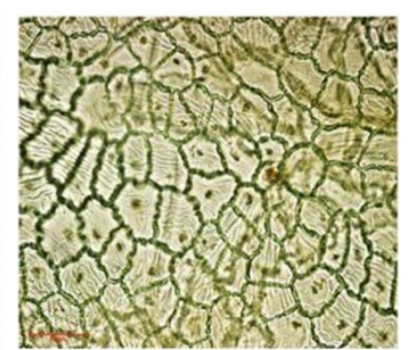

(c)

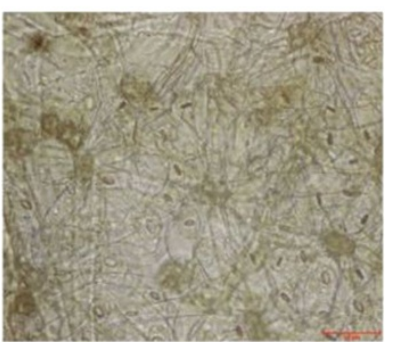

(f)

Figure 2 Adaxial epidermis (a-c) and abaxial epidermis (d-f) of Rhododendron yunnanense (a, d), R. irroratum (b, e), and $R$. delavayi (c, $\mathrm{f}$ ) under light microscope. Scale bars $50 \mu \mathrm{m}$.

R. yunnanense had the lowest value of $\mathrm{N}_{\mathrm{a}}$ and highest value of $\mathrm{N}_{\mathrm{m}}$, while $\mathrm{P}_{\mathrm{R}}, \mathrm{P}_{\mathrm{B}}$ and PNUE were highest in $R$. delavayi, but there was no significant difference among three Rhododendron species except for $\mathrm{N}_{\mathrm{m}}$. R. irroratum had the highest value for chlorophyll content per area (Chl), but the lowest ratio of chlorophyll a to $\mathrm{b}(\mathrm{Chl} \mathrm{a} / \mathrm{b})$.

\section{Relationships between leaf traits}

There was a strong linear correlation between LMA and photosynthetic capacity, as estimated by $A_{\max }$ and $V_{\max }$, although there was no significant relationship between

\section{Table 3 Leaf gas exchange parameters (Mean \pm SE) of} three Rhododendron species

\begin{tabular}{|c|c|c|c|}
\hline Parameters & R. yunnanense & R. irroratum & R. delavayi \\
\hline$A_{\max }\left(\mu \mathrm{mol} \mathrm{m}^{-2} \mathrm{~s}^{-1}\right)$ & $9.00 \pm 0.38 b$ & $11.19 \pm 0.99 a$ & $11.90 \pm 0.19 a$ \\
\hline $\mathrm{LCP}\left(\mu \mathrm{mol} \mathrm{m}^{-2} \mathrm{~s}^{-1}\right)$ & $5.16 \pm 0.63 b$ & $8.67 \pm 1.10 a$ & $10.84 \pm 0.69 a$ \\
\hline $\operatorname{LSP}\left(\mu \mathrm{mol} \mathrm{m}^{-2} \mathrm{~s}^{-1}\right)$ & $509.55 \pm 60.15 b$ & $643.68 \pm 70.34 a$ & $665.37 \pm 8.19 a$ \\
\hline$R_{d}\left(\mu m o l m^{-2} s^{-1}\right)$ & $0.35 \pm 0.04 b$ & $0.64 \pm 0.11 a$ & $0.77 \pm 0.03 a$ \\
\hline$V_{c \max }\left(\mu \mathrm{mol} \mathrm{m}^{-2} \mathrm{~s}^{-1}\right)$ & $29.00 \pm 1.00 a$ & $32.00 \pm 1.00 a$ & $32.67 \pm 1.45 a$ \\
\hline $\mathrm{C}_{\mathrm{i}}\left(\mu \mathrm{mol} \mathrm{mol}^{-1}\right)$ & $251.89 \pm 9.09 b$ & $273.94 \pm 2.49 a$ & $281.20 \pm 5.47 a$ \\
\hline $\mathrm{G}_{\mathrm{s}}\left(\mathrm{mol} \mathrm{m} \mathrm{m}^{-2} \mathrm{~s}^{-1}\right)$ & $0.144 \pm 0.015 b$ & $0.232 \pm 0.024 a$ & $0.292 \pm 0.028 a$ \\
\hline $\mathrm{T}_{\mathrm{r}}\left(\mathrm{mmol} \mathrm{m}^{-2} \mathrm{~s}^{-1}\right)$ & $1.46 \pm 0.09 c$ & $2.18 \pm 0.17 b$ & $3.00 \pm 0.30 a$ \\
\hline $\begin{array}{l}\text { WUE ( } \mu \mathrm{mol} \mathrm{CO}_{2} \mathrm{mmol} \\
\left.\qquad \mathrm{H}_{2} \mathrm{O}^{-1}\right)\end{array}$ & $5.90 \pm 0.31 a$ & $4.83 \pm 0.09 b$ & $3.81 \pm 0.37 c$ \\
\hline
\end{tabular}

Amax, light- saturated photosynthetic rate; LCP, light compensate point; LSP, light saturate point; $\mathrm{Rd}$, dark respiration rate; $\mathrm{Vcmax}$, maximum rate of RuBP carboxylation; Gs, stomatal conductance; $\mathrm{Ci}$, intercellur $\mathrm{CO} 2$ concentration; $\mathrm{Tr}$, transpiration rate; WUE, photosynthetic water use efficiency. Different letters in the same row indicate statistical difference $(p<0.05)$.
$\mathrm{A}_{\max }$ and $\mathrm{N}$ content either base on leaf area or leaf mass (Figure 3). In addition to relating with photosynthetic capacity, LMA showed a negatively correlation with $\mathrm{N}_{\mathrm{m}}$ or WUE, and a positive correlation was found between LMA and $\mathrm{G}_{\mathrm{s}}$ (Figure 4).

\section{Discussion}

Correlation between leaf structure and natural habitat

Plants often exhibit considerable variations in their functional traits that affect the capture and utilization of resources and enable them to adapt to changing environments (Guan et al. 2011). Cuticles can reduce water loss from the leaf to the atmosphere, and considered as an

\section{Table 4 Leaf traits of three Rhododendron species}

\begin{tabular}{lccc}
\hline Parameters & R. yunnanense & R. irroratum & R. delavayi \\
\hline LMA $\left(\mathrm{g} \mathrm{m}^{-2}\right)$ & $59.38 \pm 1.90 \mathrm{~b}$ & $94.32 \pm 2.97 \mathrm{a}$ & $87.08 \pm 3.33 \mathrm{a}$ \\
$\mathrm{N}_{\mathrm{a}}\left(\mathrm{g} \mathrm{m}^{-2}\right)$ & $0.98 \pm 0.05 \mathrm{a}$ & $1.20 \pm 0.12 \mathrm{a}$ & $1.01 \pm 0.09 \mathrm{a}$ \\
$\mathrm{N}_{\mathrm{m}}\left(\mathrm{mg} \mathrm{g}^{-1}\right)$ & $16.50 \pm 1.18 \mathrm{a}$ & $12.69 \pm 1.21 \mathrm{ab}$ & $11.67 \pm 1.15 \mathrm{~b}$ \\
$\mathrm{P}_{\mathrm{R}}\left(\mathrm{g} \mathrm{g}^{-1}\right)$ & $0.378 \pm 0.008 \mathrm{a}$ & $0.344 \pm 0.023 \mathrm{a}$ & $0.414 \pm 0.029 \mathrm{a}$ \\
$\mathrm{P}_{\mathrm{B}}\left(\mathrm{g} \mathrm{g}^{-1}\right)$ & $0.088 \pm 0.001 \mathrm{a}$ & $0.087 \pm 0.010 \mathrm{a}$ & $0.095 \pm 0.006 \mathrm{a}$ \\
$\mathrm{PNUE}\left(\mu \mathrm{mol} \mathrm{g}^{-1} \mathrm{~s}^{-1}\right)$ & $9.26 \pm 0.59 \mathrm{a}$ & $9.44 \pm 0.85 \mathrm{a}$ & $11.92 \pm 0.97 \mathrm{a}$ \\
$\mathrm{Chl} \mathrm{a}+\mathrm{b}\left(\mu \mathrm{g} \mathrm{m}^{-2}\right)$ & $62.91 \pm 2.85 \mathrm{a}$ & $66.05 \pm 4.18 \mathrm{a}$ & $57.58 \pm 4.87 \mathrm{a}$ \\
$\mathrm{Chl} \mathrm{a/} \mathrm{b}$ & $2.43 \pm 0.06 \mathrm{ab}$ & $2.25 \pm 0.52 \mathrm{~b}$ & $2.53 \pm 0.08 \mathrm{a}$
\end{tabular}

LMA, leaf mass per unit area; $\mathrm{Na}$, leaf nitrogen content per unit area; $\mathrm{Nm}$, leaf nitrogen content per unit mass; $P R$, the partitioning coefficients of leaf nitrogen in RuBPCO; PB, the partitioning coefficients of leaf nitrogen in bioenergetics; PNUE, photosynthetic nitrogen use efficiency; Chl $a+b$, chlorophyll content of $\mathrm{a}$ and $\mathrm{b} ; \mathrm{Chl} \mathrm{a} / \mathrm{b}$, the ratio of chlorophyll $\mathrm{a}$ and $\mathrm{b}$. Different letters in the same row indicate statistical difference $(p<0.05)$. 

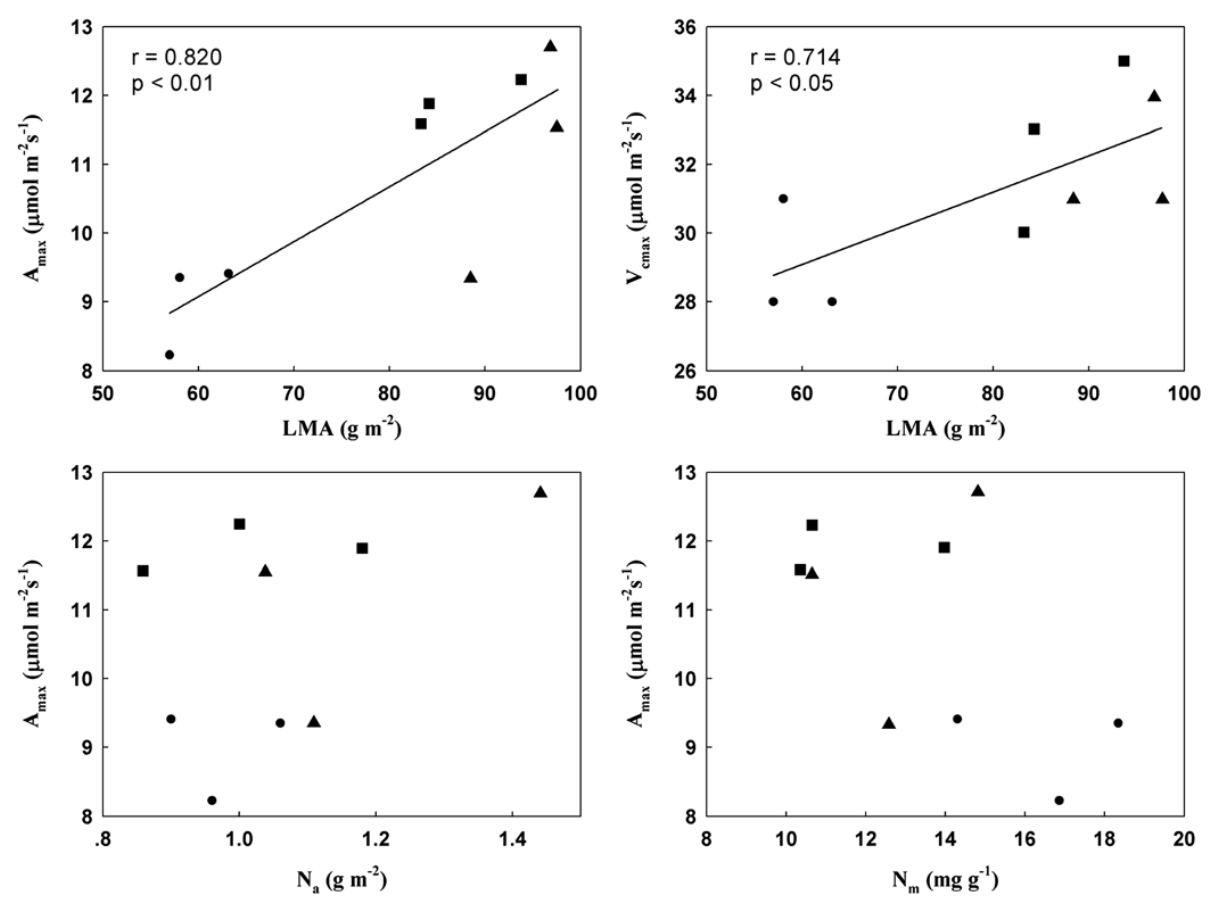

Figure 3 Correlations between leaf dry mass per unit area (LMA) and light-saturated photosynthetic rate $\left(A_{\max }\right)$ or maximum rates of carboxylation $\left(\mathrm{V}_{\mathrm{cmax}}\right)$; and between $\mathrm{A}_{\max }$ and leaf nitrogen content per unit area $\left(\mathrm{N}_{a}\right)$ or leaf nitrogen content per unit mass $\left(\mathrm{N}_{\mathrm{m}}\right)$ in three Rhododendron species. " $\bullet$ ", " $\mathbf{\Delta}$ " and "m" stand for R. yunnanense, R. irroratum and R. delavayi, respectively.

ecological characteristic for plant confront to high light and drought. The cuticle of $R$. irroratum was thicker than $R$. yunnanense, whereas $R$. delavayi did not have a thicker cuticle than $R$. irroratum. However, the abaxial surface of $R$. delavayi with 1-layered spongy, or somewhat agglutinated indumentum (Figure 2f), can reduce water loss from the leaf interior and prevent light damage, and thus increase water use efficiency and maintain normal leaf physiological function (Mill and Stark Schilling 2009). The results indicate $R$. yunnanense is vulnerable to moisture and light stress, whereas $R$. irroratum and $R$. delavayi may be better suited to drier and brighter habitats.

Stoma effectively regulates gas exchange where water vapor leaves the plant and $\mathrm{CO}_{2}$ enters. The stomatal distribution, density, size, morphology and behavior are closely associated with environmental factors (Schlüter et al. 2003). The significantly negative correlation found between stomatal size and stomatal density in three Rhododendron species, i.e., $R$. delavayi with more densely but smaller stomata and $R$. yunnanense showed opposite trends (Table 2). Stomatal density is closely related to water availability and light intensity (Cai et al. 2004). Generally speaking, strong light and water deficit lead to more densely but small stomata (Xu and Zhou 2008). Small stomata enable the leaf to attain high and rapid diffusive conductance under favorable conditions, and they afford greater water use efficiency in dry habitats because they can react more quickly to environmental stimuli (Franks et al. 2009). By contrast, larger stomata are slower to close and have a greater potential for hydraulic dysfunction under conditions of drought, however, this lag in response may be advantageous in cool, moist, or shaded environments (Aasamaa et al. 2001). The results indicated that $R$. delavayi with more densely but smaller stomata may have a strong ability to regulate water/ $/ \mathrm{CO}_{2}$ and may be better suited to more arid and high light environments than are $R$. yunnanense or $R$. irroratum. This is consistent with our observation of these species' natural habitats.

LMA is a key structural trait that measures plant investment and is widely used as an indicator of plant ecological strategies (Westoby et al. 2002). A high LMA was associated with high leaf thickness and more structural tissue, and has been interpreted as a property to drought or high light environment (Salleo and Lo Gullo 1990). However, in present study, LMA didn't show a positive correlation with leaf thickness. LMA of $R$. yunnanense was significantly lower than $R$. delavayi and $R$. irroratum (Table 4), but its leaf was thicker. Leaf mesophyll (palisade and spongy tissue) mainly contributed to a thicker leaf (Table 2). Witkowski and Lamont (1991) point out that both leaf thickness and density may account for changes in LMA and both traits may vary independently. Moreover, anatomical structure underlying variation in leaf density and thickness may differ depending on the nature of the 


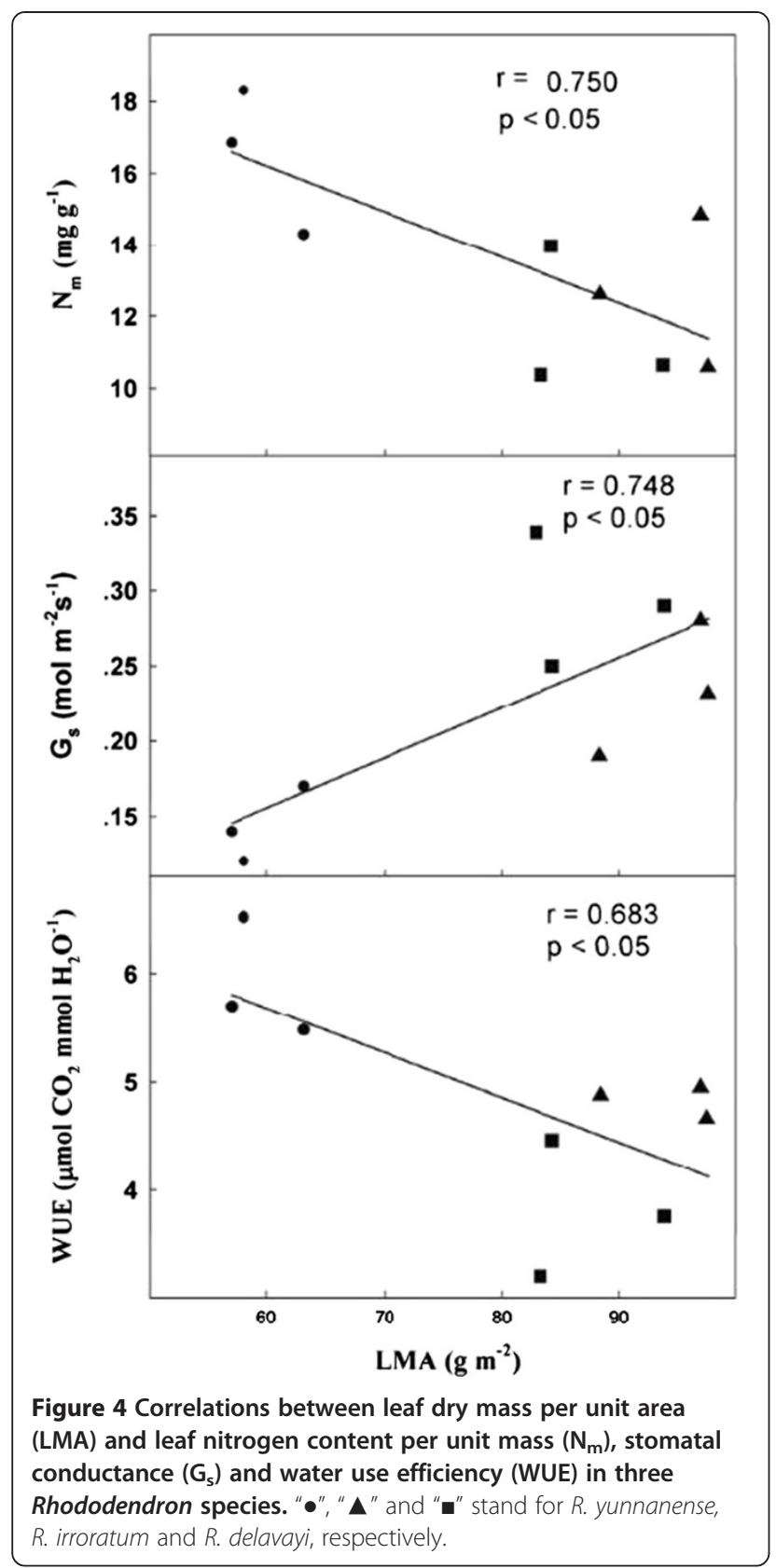

species and their environment (Garnier and Laurent 1994; Van Arendonk and Poorter 1994; Poorter et al. 2009). Castro-Díez et al. (2000) found LMA in 52 European woody species was correlated with leaf density but not with thickness. Greater LMA across these species set as greater allocation to support and defense functions, as shown predominantly by species from resource-poor environment.

\section{Correlation between leaf physiological function and natural habitat}

Light has been justified as the main factor determining a plant's survival, growth, and fitness. Upon exposure to a wide range of light regimes, plants show an ability to meet these differing conditions, mainly by alterations in leaf structure and biochemistry (Evans 1989; Niinemets and Tenhunen 1997). LCP and LSP of R. delavayi and $R$. irroratum were higher than $R$. yunnanense, indicating their photosynthetic apparatus can operate well in higher light environment and benefiting to survival and occupy higher light habitats. The study of Nilsen et al. (1988) about $R$. maximum also reported that in the open environment, the rate of light saturated photosynthesis was reached earlier in the day than that of low light environments. For shade-tolerant $R$. yunnanense, lower LCP, LSP, and Rd would benefit greater net carbon gain in low-light, and suggest this species may be a strong competitor in low-light environments.

Because more than $50 \%$ of total leaf nitrogen is allocated to the photosynthetic apparatus, total leaf nitrogen content affects the biochemical efficiency of assimilation (Evans 1989). Generally, the leaves on plants grown under low light have more nitrogen content per mass than those exposed to high light, this is because shade leaves contain less mechanical tissue per unit area than do sun leaves (Evans and Poorter 2001). Our studies also yielded similar results. $R$. delavayi and $R$. irroratum had higher $\mathrm{N}_{\mathrm{a}}$ than $R$. yunnanense, whereas $\mathrm{N}_{\mathrm{m}}$ showed opposite trend. However, we didn't find a close linear relationship between $\mathrm{A}_{\max }$ and leaf nitrogen content, both in the terms of $N_{a}$ and $N_{m}$ (Figure 3). Previous studies showed that under high irradiance, the photosynthetic rate is co-regulated more by investments of leaf $\mathrm{N}$ to carboxylation and electron transport (i.e., $\mathrm{P}_{\mathrm{R}}$ and $\mathrm{P}_{\mathrm{B}}$ ) compared with low irradiance (Hikosaka and Terashima 1996). In the present study, the three Rhododendron species studied had relative constant $P_{R}$ and $P_{B}$ values, but $R$. delavayi and $R$. irroratum had higher $\mathrm{A}_{\max }$ and thus effectively enhance PNUE (Table 4). Efficient nitrogen use in photosynthetic machinery in accordance with the environment may enhance the fitness of these species in infertile habitats (Hassiotou et al. 2010). These results may imply that $R$. delavayi and $R$. irroratum have a broader ecological niche than $R$. yunnanense, however, leaf $\mathrm{N}$ content and leaf $\mathrm{N}$ reorganization did not meaningfully influence their physiological performance.

\section{Correlation between leaf structure and physiological function}

The differences in photosynthetic capacity reflected the differences in leaf anatomy, physiology, and biochemistry. Stomata can effectively regulate gas exchange where water vapor exits the plant and $\mathrm{CO}_{2}$ enters. Leaf conductance, photosynthetic carbon gain and the potential transpiration rate are primarily determined by both stomatal aperture and density (Brodribb and Jordan 2011; Büssis et al. 2006). The stomata of $R$. delavayi and 
$R$. irroratum were more densely packed and smaller than $R$. yunnanense, and as a result, stomatal conductance and transpiration rate were nearly twice that of $R$. yunnanense (Table 3). As the ability of leaves to quickly open stomata and increase conductance may allow greater rates of carbon fixation to occur, so densely and small stomata partly contributed to larger stomatal conductance, and consequently higher photosynthetic rate of $R$. delavayi and $R$. irroratum.

Leaf structure as indicated by LMA was also positively correlated with $G_{s}$ and photosynthetic capacity of the three Rhododendron species. The plant with higher LMA usually had greater surface area of leaf chloroplast $\left(\mathrm{S}_{\text {mes }}\right)$ or mesophyll cells facing intercellular air spaces per area $\left(\mathrm{S}_{\mathrm{c}}\right)$, and consequently, mesophyll conductance and photosynthetic capacity (Terashima et al. 2001; Oguchi et al. 2003; Piel et al. 2002). Our study demonstrates that high $S_{\text {mes }}$ and $S_{\text {c }}$ were mainly due to thick palisade tissue. Notably, palisade thickness along with $S_{\mathrm{c}}$ may enhance the capture of photons on an area basis. Furthermore, the high $S_{\mathrm{c}}$ can enhance the diffusion of $\mathrm{CO}_{2}$ from the surface of mesophyll cells to chloroplasts, resulting in the positive correlation between $S_{\mathrm{c}}$ and $A_{\max }$ (Oguchi et al. 2005). However, other studies have suggested that high LMA has been associated with low mesophyll conductance, which can restrict the rate of $\mathrm{CO}_{2}$ assimilation (Terashima et al. 2006; Hassiotou et al. 2009). The negative effect of LMA on gas exchange can arise from changes in internal anatomy and an increase in the diffusion resistance of $\mathrm{CO}_{2}$ from the substomatal cavity to the chloroplasts (Niinemets 1999). Leaf surface properties including wax layers, epidermal cell shape, cuticular thickening, trichomes, mesophyll cell wall thickness and stomatal crypts contribute to high LMA, and can alter leaf structural properties and thus influence gas exchange (Terashima et al. 2005; Terashima et al. 2006).

Changes in LMA are caused by variations in internal anatomy, and there may also be secondary effect on foliar $\mathrm{N}$ content or $\mathrm{N}$ allocation to the photosynthetic machinery (Garnier and Laurent 1994). High LMA is often associated with more structural tissue and lower nitrogen content, but whether this is simply due to 'dilution' by the presence of more structural tissue, or also applies to the photosynthetic apparatus is not well understood (Hassiotou et al. 2010; Hikosaka 2004). In the present study, a negative linear relationship between LMA and $\mathrm{N}_{\mathrm{m}}$ and a positive relationship between LMA and $\mathrm{A}_{\max }$ were found in three Rhododendron species, but $\mathrm{N}$ content didn't show significantly correlation with photosynthetic capacity either base on leaf area or leaf mass (Figure 3). The results suggest that more structural tissue in the three Rhododendron species, resulted lower mass-based nitrogen content, and changes in leaf photosynthesis, but importantly, these results did not arise from disparate $\mathrm{N}$ partitioning within leaves. However, in a comprehensive study of 25 species covering a 10-fold range in LMA, Harrisonlk et al. (2009) showed that the fraction of nitrogen allocated to cell walls is independent of LMA, and the relationship between the fraction of nitrogen allocated to Rubisco and LMA is curvilinear. These relationships between leaf $\mathrm{N}$ and leaf structure may arise because under field conditions, differences in stomatal conductance may dominate photosynthetic functioining, whereas differences in $\mathrm{N}$ content and internal leaf anatomy have only a marginal effect on photosynthetic functioning Mediavilla et al. (2001).

\section{Conclusion}

In conclusion, three Rhododendron species exhibited significant differences in leaf anatomical and physiological characteristics related to their natural habitats. When compared with $R$. yunnanense, the divergence in leaf anatomical structures and physiological functioning of $R$. delavayi and $R$. irroratum reflected stronger ecophysiological performance to a higher light and drier environment. Variation in leaf photosynthesis across species was associated with variation in LMA, but not leaf nitrogen.

\section{Competing interests}

The authors declare that they have no competing interests of this research.

\section{Authors' contributions}

C-YF, L-SF and L-SF designed the experiments together. C-YF measured photosynthesis, related leaf traits analyzed data. L-SF and L-SF investigated natural habitat and managed experimental materials. X-WJ made the observation of leaf anatomy, S-J made the observation of stomatal traits. All authors read and approved the final manuscript.

\section{Acknowledgements}

This work is financially supported by the Science and Technology Foundation of Yunnan (2011 EB110) and the Open Foundation of the Key Laboratory of Yunnan Flower Breeding (FKL-201003).

\section{Author details}

${ }^{1}$ Flower Research Institute of Yunnan Academy of Agricultural Sciences, Kunming 650205, China. ${ }^{2}$ Yunnan Flower Breeding Key Lab, Kunming 650204, China. ${ }^{3}$ Yunnan Flower Research and Development Center, Kunming 650205, China.

Received: 10 August 2012 Accepted: 7 November 2013 Published: 20 March 2014

\section{References}

Aasamaa K, Söber A, Rahi M (2001) Leaf anatomical characteristics associated with shoot hydraulic conductance, stomatal conductance and stomatal sensitivity to changes of leaf water status in temperate deciduous trees. Funct Plant Biol 28:765-774

Brodribb TJ, Jordan GJ (2011) Water supply and demand remain balanced during leaf acclimation of Nothofagus cunninghamii trees. New Phytol 192:437-448

Büssis D, von Groll U, Fisahn J, Altmann T (2006) Stomatal aperture can compensate altered stomatal density in Arabidopsis thaliana at growth light conditions. Funct Plant Biol 33:1037-1043

Cai ZQ, Qi X, Cao KF (2004) Response of stomatal characteristics and its plasticity to different light intensities in leaves of seven tropical woody seedlings. Chin J Appl Ecol 15:201-204 (in Chinese) 
Castro-Díez P, Puyravaud JP, Cornelissen JHC (2000) Leaf structure and anatomy as related to leaf mass per area variation in seedlings of a wide range of woody plant species and types. Oecologia 124:476-486

Cordero RA, Nilsen ET (2002) Effects of summer drought and winter freezing on stem hydraulic conductivity of Rhododendron species from contrasting climates. Tree Physiol 22:919-928

Cui HX, Jiang GM, Niu SL, Li YG, Jiang CD, Liu MZ, Gao LM (2004) Gas exchanges of an endangered species Syringa pinnatifolia and a widespread congener S. oblata. Photosynthetica 42:529-534

Dunbar-Co S, Sporck MJ, Sack L (2009) Leaf trait diversification and design in seven rare taxa of the Hawaiian Plantago radiation. Int J Plant Sci 170:61-75

Evans JR (1989) Photosynthesis and nitrogen relationships in leaves of C3 plants. Oecologia 78:9-19

Evans JR, Poorter H (2001) Photosynthetic acclimation of plants to growth irradiance: the relative importance of specific leaf area and nitrogen in maximizing carbon gain. Plant Cell Environ 24:755-767

Fang MY, Fang RZ, He MY, Hu LZH, Yang HP (2005) Flora of China, 14th edition. Science Press, Beijing, pp 260-455

Feng YL (2008) Nitrogen allocation and partitioning in invasive and native Eupatorium species. Physiol Plant 132:350-358

Franks PJ, Drake PL, Beerling DJ (2009) Plasticity in maximum stomatal conductance constrained by negative correlation between stomatal size and density: an analysis using Eucalyptus globulus. Plant Cell Environ 32

Garnier E, Laurent G (1994) Leaf anatomy, specific mass and water content in congeneric annual and perennial species. New Phytol 128:725-736

Guan ZJ, Zhang SB, Guan KY, Li SY, Hu H (2011) Leaf anatomical structures of Paphiopedilum and Cypripedium and their adaptive significance. J Plant Res 124:289-298

Harrisonlk MT, Edwards EJ, Farquhar GD, Nicotra AB, Evans JR (2009) Nitrogen in cell walls of sclerophyllous leaves accounts for little of the variation in photosynthetic nitrogen-use efficiency. Plant Cell Environ 32:259-270

Hassiotou F, Ludwig M, Renton M, Veneklaas EJ, Evans JR (2009) Influence of leaf dry mass per area, $\mathrm{CO}_{2}$ and irradiance on mesophyll conductance in sclerophylls. J Exp Bot 60:2303-2314

Hassiotou F, Renton M, Ludwig M, Evan JR, Veneklaas EJ (2010) Photosynthesis at an extreme end of the leaf trait spectrum: how does it relate to high leaf dry mass per area and associated structural parameters? J Exp Bot 61:3015-3028

Hikosaka K (2004) Interspecific difference in the photosynthesis-nitrogen relationship: patterns, physiological causes, and ecological importance. J Plant Res 117:481-494

Hikosaka K, Terashima I (1996) Nitrogen partitioning among photosynthetic components and its consequences in sun and shade plants. Funct Ecol 10:335-343

Inskeep WP, Bloom PR (1985) Extinction coefficients of chlorophyll a and b in N, $\mathrm{N}$ - dimethylformamide and 80\% acetone. Plant Physiol 77:483-485

Kikuzawa K (1995) Leaf phenology as an optimal strategy for carbon gain in plants. Can J Bot 73:158-163

Le Roux X, Grand S, Dreyer E, Daudet FA (1999) Parameterization and testing of a biochemically based photosynthesis model for walnut (Juglans regia) trees and seedlings. Tree Physiol 19:481-492

Le Roux X, Walcroft AS, Daudet FA, Sinoquet H, Chaves MM, Rodrigues A, Osorio L (2001) Photosynthetic light acclimation in peach leaves: importance of changes in mass: area ratio, nitrogen concentration, and leaf nitrogen partitioning. Tree Physiol 21:377-386

Lin MJ, Hsu BD (2004) Photosynthetic Phalaenopsis in response to different light environments. J Plant Physiol 161:1259-1268

Mediavilla S, Escudero A, Heilmeier H (2001) Internal leaf anatomy and photosynthetic resource-use efficiency: interspecific and intraspecific comparisons. Tree Physiol 21:251-259

Mill RR, Stark Schilling DM (2009) Cuticle micromorphology of Saxegothaea (Podocarpaceae). Bot J Linn Soc 159:58-67

Niinemets Ü (1999) Components of leaf dry mass per area-thickness and density-alter leaf photosynthetic capacity in reverse directions in woody plants. New Phytol 144:35-47

Niinemets Ü, Tenhunen JD (1997) A model separating leaf structural and physiological effects on carbon gain along light gradients for the shade-tolerant species Acer saccharum. Plant Cell Environ 20:845-866

Nilsen ET, Stetler DA, Gassman CA (1988) Influence of age and microclimate on the photochemistry of Rhododendron maximum leaves II. Chloroplast structure and photosynthetic light response. Am J Bot 75:1526-1534
Oguchi R, Hikosaka K, Hirose T (2003) Does the photosynthetic light-acclimation need changes in leaf anatomy? Plant Cell Environ 26:505-512

Oguchi R, Hikosaka K, Hirose T (2005) Leaf anatomy as a constraint for photosynthetic acclimation: differential responses in leaf anatomy to increasing growth irradiance among three deciduous trees. Plant Cell Environ 28:916-927

Pandey SK, Singh H, Singh JS (2009) Species and site effects on leaf traits of woody vegetation in a dry tropical environment. Curr Sci 96:1109-1114

Piel C, Frak E, Le Roux Z, Genty B (2002) Effect of local irradiance on CO2 transfer conductance of mesophyll in walnut. J Exp Bot 53:2423-2430

Poorter L, Bongers F (2006) Leaf traits are good predictors of plant performance across 53 rain forest species. Ecology 87:1733-1743

Poorter H, Niinemets Ü, Poorter L, Wright IJ, Villar R (2009) Causes and consequences of variation in leaf mass per area (LMA): a meta-analysis. New Phytol 182:565-588

Salleo S, Lo Gullo MA (1990) Sclerophylly and plant water relations in three Mediterranean species. Ann Bot 65:259-270

Scagel CF (2007) Seasonal variation in growth, nitrogen uptake and allocation by container-grown evergreen and deciduous Rhododendron cultivars. HortSci 42:1440-1449

Schlüter U, Muschak M, Berger D, Altmann T (2003) Photosynthetic performance of an Arabidopsis mutant with elevated stomatal density (sdd1-1) under different light regimes. J Exp Bot 54:867-874

Terashima I, Miyazawa SI, Hanba YT (2001) Why are sun leaves thicker than shade leaves? Consideration based on analyses of $\mathrm{CO}_{2}$ diffusion in the leaf. J Plant Res 114:93-105

Terashima I, Araya T, Miyazawa SI, Sone K, Yano S (2005) Construction and maintenance of the optimal photosynthetic systems of the leaf, herbaceous plant and tree: an eco-developmental treatise. Ann Bot 95:507-519

Terashima I, Hanba YT, Tazoe Y, Vyas P, Yano S (2006) Irradiance and phenotype: comparative eco-development of sun and shade leaves in relation to photosynthetic $\mathrm{CO}_{2}$ diffusion. J Exp Bot 57:343-354

Van Arendonk JJCM, Poorter H (1994) The chemical composition and anatomical structure of leaves of grass species differing in relative growth rate. Plant Cell Environ 17:963-970

Vendramini F, Diaz S, Gurvich DE, Wilson PJ, Thompson K, Hodgson JG (2002) Leaf traits as indicators of resource-use strategy in floras with succulent species. New Phytol 154:147-157

Von Caemmerer S, Farquhar GD (1981) Some relationships between the biochemistry of photosynthesis and the gas exchange rates of leaves. Planta 153:376-387

Wang X, Peng YH, Singer JW, Fessehaie A, Krebs SL, Arora R (2009) Seasonal changes in photosynthesis, antioxidant systems and ELIP expression in a thermonastic and non-thermonastic Rhododendron species: a comparison of photoprotective strategies in overwintering plants. Plant Sci 177:607-617

Watling JR, Press MC, Quick WP (2000) Elevated $\mathrm{CO}_{2}$ induces biochemical and ultrastructural changes in leaves of C4 cereal sorghum. Plant Physiol 123:1143-1152

Weng JH, Ueng RG (1997) Effect of temperature on photosynthesis of Miscanthus clones collected from different elevations. Photosynthetica 34:307-311

Westoby M, Falster DS, Moles AT, Vesk PA, Wright IJ (2002) Plant ecological strategies: some leading dimensions of variation between species. Ann Rev Eco Syst 33:125-159

Witkowski ETF, Lamont BB (1991) Leaf specific mass confounds leaf density and thickness. Oecologia 88:486-493

Xu ZZ, Zhou GS (2008) Responses of leaf stomatal density to water status and its relationship with photosynthesis in a grass. J Exp Bot 59:3317-3325

Zhang SB, Yin LX (2012) Plasticity in photosynthesis and functional leaf traits of Meconopsis horridula var. racemosa in response to growth irradiance. Bot Stud 53:335-343

\section{doi:10.1186/1999-3110-55-36}

Cite this article as: Cai et al:: How do leaf anatomies and photosynthesis of three Rhododendron species relate to their natural environments? Botanical Studies 2014 55:36. 